\title{
Homage to Orio Giarini and a summary of Four Pillars Research Programme
}

\author{
Geneviève Reday-Mulvey ${ }^{1}$
}

Accepted: 24 February 2021 / Published online: 14 April 2021

(c) The Author(s) 2021

For over 15 years I had the great privilege of working with Professor Orio Giarini, first Secretary General of The Geneva Association. Throughout my working lifeand until his demise last March-Orio Giarini had been, for me, an inspiration and a real 'maître à penser'. He had the ability to make you think about economics in a totally different way that was both positive and controversial. Moreover, he was generally a kind and happy man and generous with support, both professional and personal, when he felt that you needed it.

Let me recall a couple of short anecdotes that illustrate the man that Orio was. I was 40 when I met him again (I had started my career at the Battelle Institute in the Department of Applied Economics he had directed). We immediately embarked upon a stimulating discussion about long-term social and economic trends and he asked me, without even looking at my CV, "Would you like to work with us? We shall do interesting work and you will enjoy it", adding in French "on va beaucoup travailler mais on va bien s'amuser".

After two years working with the Association, I decided to move to London with my family and told him how much I regretted having to leave The Geneva Association. He looked at me and said "Are you going to the Amazon?" "No, just to London" I replied. Then he said "I'm not going to let you leave us, you will be the first of our researchers (we were a very small team at that time, just four of us) not to have a secretary and to work on a computer-buy an Apple and get some training in London. That is the future! Soon we shall not need much secretarial work", adding "London is more interesting for research on pension issues than Geneva. Good luck!".

During my time in London, where the conferences and seminars I attended or contributed to were numerous, I went to New York to organise one of the Association's first sessions on 'the Four Pillars' at a big conference. This must have been in the early 1990s. I had selected three good American speakers but the attendance was

Geneviève Reday-Mulvey-Retired, The Geneva Association.

Geneviève Reday-Mulvey

gfmulvey@orange.fr

1 Solidarités St Julien-St Louis, 1B Promenade du Crêt, 74160 St-Julien-en-Genevois, France 
tiny, only six or seven participants. To my surprise, during my introduction I saw Orio enter the room (I knew he was in the States but not in New York) and sit down. I must have turned white since I was ashamed of the small number of attendees. At the end of the session when I apologised to him about this, he replied "Of course, our ideas are too advanced for people. Often, things start with a handful of people who see the future before others do. In 10 years you will have 150 participants and your ideas will become popular. Success takes time!". And how right he was! The Four Pillars Research Programme went from strength to strength, securing the collaboration of some of the best researchers and experts in several OECD countries and international organisations, setting up important conferences and producing a number of publications and books which, in many ways, still remain up-to-date.

\section{A summary of the Four Pillars Research Programme and its achievements}

What is really ageing is the notion of older age itself. Statistics based on the capacity to perform indicate that the population is 'rejuvenating': we now live in a 'counter-ageing society'. Orio Giarini

The Geneva Association launched its 'Four Pillars' Research Programme with a view to identifying possible solutions to the issue of the future financing of pensions and, more generally, to reorganising social security systems. Demographic trendsespecially increased life expectancy_might be positive, as long as we could devise ways of enabling ageing in good health to ensure valid economic and social contributions to the functioning of our service economies in the decades to come.

The research programme had four main objectives:

- To identify the key elements in organising old-age security systems

- To research the conditions for multi-pillar systems for financing pensions

- To encourage multiple and complementary solutions to the challenges of ageing

- To better understand the role of insurance in the provision of old-age security systems.

\section{History of the concept}

Since the early 1990s, the dependency ratio of non-active retirees to the active population had begun to shift significantly: from a ratio of 1:5 in 1990 it was expected to reach less than $1: 3$ by 2020 . However, demographic and financial constraints were occurring in an economic context, where four jobs out of five were in service functions. Such service activities are typically less physically demanding but require greater mental abilities, meaning that, in principle, workers could easily remain productive for longer, especially if retirement conditions could be made more flexible and adequate continuing training, among other things, made more available.

In this way, it might be possible to turn demographic problems into opportunities, provided older workers could be kept working for longer on a flexible basis. The 
new challenge was about to affect the entire planet: "this issue will soon be a worldwide one since in 2025 over $70 \%$ of the ageing population (60s and over) will live in the developing countries" (Social and Economic Council, United Nations).

The programme's name 'Four Pillars' owed its origin to the fact that, in most OECD countries, the funding of pensions mainly came (and still comes) from resources drawn from three existing pillars:

- The first pillar: compulsory state/public pension, based on the pay-as-you-go principle;

- The second pillar: supplementary occupational pension, normally based on funding. Compulsory in several countries and encouraged in others

- The third pillar: made up of individual savings (personal pensions, property and investments, as well as life insurance products).

We called our research programme The Four Pillars because, from the start (1987), we considered adding a fourth pillar (income from work —often part-timeafter pension age) as a fundamental part of the future financing of pensions, and more widely, of social security. This terminology has now become standard usage in European Commission and OECD publications and presentations.

\section{Overcoming the longevity challenge: consolidation of a multi-pillar pension}

Achieving an entirely new design for retirement is every bit as necessary as consolidating the sources from which it is to be funded.

Denis Kessler

An important finding of The Geneva Association's research was that first pillar pensions would need to continue to play an important role for the majority of populations, but that occupational and personal pensions, as they became more widespread, should be used to offset any relative fall in the value of first pillar pensions in future decades and to consolidate retirement systems overall. Our approach was therefore to study the advantages of supplementing public social policies (one of the twentieth century's most significant achievements) by private solutions, and to address the shift in the balance between the public and private sectors by stressing the importance of developing the latter. The capitalisation-based second pillar was also seen as made for greater adaptability in the context of increasingly common flexible careers - a feature of the new service economy - and the cross-border labour market. It should also be noted that we were always advocates of a solid regulatory framework, which we believed was indispensable to the widespread development of occupational or second pillar pension schemes.

The Geneva Association's primary purpose in this field was to stimulate reflection among its membership, as well as participate in academic and public policy discussions about the crucial changes affecting the first three pillars. Indeed, the development of a capitalisation-based second pillar (already compulsory in certain countries like the Netherlands, Switzerland, Australia and the Nordic countries), progressively 
Table 1 Retirement expectancy in several European countries

\begin{tabular}{|c|c|c|c|c|c|c|}
\hline & \multicolumn{2}{|c|}{$\begin{array}{l}\text { Average age of } \\
\text { exit from work }\end{array}$} & \multicolumn{2}{|c|}{$\begin{array}{l}\text { Life expectancy } \\
\text { at } 65\end{array}$} & \multicolumn{2}{|c|}{$\begin{array}{l}\text { Retirement } \\
\text { expectancy }\end{array}$} \\
\hline & Men & Women & Men & Women & Men & Women \\
\hline Denmark & 62.1 & 60.8 & 16.2 & 19.1 & 19.1 & 23.3 \\
\hline France & 59.1 & 58.9 & 18.2 & 22.6 & 23.1 & 28.7 \\
\hline Germany & 62.1 & 60.5 & 17.2 & 20.5 & 20.1 & 25.0 \\
\hline Italy & 60.2 & 59.6 & 18.8 & 21.8 & 23.6 & 26.2 \\
\hline Netherlands & 63.1 & 61.8 & 16.8 & 20.6 & 18.7 & 23.8 \\
\hline Sweden & 63.7 & 63.3 & 17.7 & 20.9 & 18.1 & 22.6 \\
\hline U.K. & 62.9 & 62.1 & 17.3 & 19.6 & 19.4 & 22.5 \\
\hline
\end{tabular}

Source Eurostats 2008 and own calculations

became the focus of international seminars organised at the Association's initiative, or with its assistance, and began to attract the attention of the European Commission and the OECD, becoming the subject of numerous publications.

The insurance industry was of course very concerned with developing second and third pillar pensions and offering savings products to improve the financial prospects of baby boomers entering retirement and to cover the long-term care needs of older cohorts. Life insurance was indeed well developed in a number of countries.

\section{Pension reforms in a long-life society}

If most European and OECD member countries had very different pension systems 30 years ago, reforms had brought these systems much closer together. Regulations at the country level as well as at the EU and OECD levels made conditions safer and more homogeneous from one state to the next, thus encouraging greater mobility.

\section{Retirement expectancy}

Both increases in life expectancy (and life expectancy in good health) and, on the whole, excellent coverage of the retired population by pension systems must be seen as triumphs of the twentieth century. Initially, pension schemes were set up to provide a replacement income during a short period, but after the Second World War significant improvements allowed them to finance a much longer retirement period. What we were first to call 'retirement expectancy' ${ }^{1}$ has increased to an extremely long period: on average, over 20 years for men and over 25 for women (Statista 2020). But, as Table 1 shows, retirement expectancy differs considerably from country to country. For example, the difference between Sweden and France

\footnotetext{
${ }^{1}$ Retirement expectancy is the number of years a person is expected to live from his/her exit age from work to death, a very useful concept in terms of pension financing.
} 
Fig. 1 A holistic approach

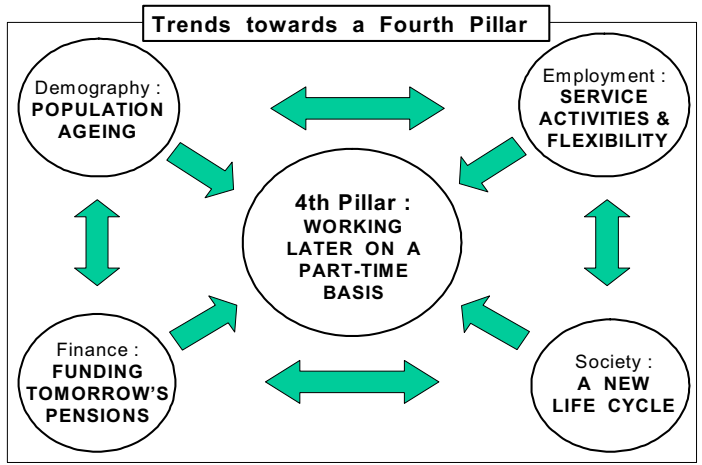

Source Reday-Mulvey, The Geneva Association 1995

was revealing. This meant that, in several European countries, there was room for improvement.

The data shown in Table 1, prepared over a decade ago, are still valid today. Life expectancy has continued to increase a little in most countries, but the average age of exit from work has also increased, making retirement expectancy about the same as in 2008 .

\section{Key issues for financing adequate and sustainable four-pillar retirement income}

1. Public-private partnerships: Public and private actors must work hand-in-hand and responsibly, as has been the case in most instances. The relationship between public social security and private pension funds is clearer today and most of us are convinced that social security pensions cannot be replaced entirely by private schemes. The experience of Chile, among others, taught the World Bank and the unconvinced among us a lesson. What countries needed was a realistic first-pillar state (or publicly-controlled) pension, i.e. adequate and sustainable, supplemented by strong and safely regulated second occupational pension funds for all workers.

Pension reforms have made public pensions relatively less generous (but often fairer between social and socio-professional groups) and are now well supplemented by occupational pensions made available to most of the working population. We insisted that they had to be developed further and be governed by adequate safety regulations such as OECD Guidelines on Funding and Benefit Security in Occupational Pensions. The 2008 crisis had a positive impact on stricter and safer regulation.

2. The need for holistic approaches: Financing over 20 years of retirement needed and needs strong, holistic policies. Pension reforms must go hand-in-hand with employment and social policies in order to encourage people to be more responsible for preparing their retirement income and be ready to work later in life. Disincentives to leave work early and financial incentives to remain at work until pension age (and beyond on a part-time basis or with adapted working conditions) gradually combined to create a new consensus and culture regarding a longer working 
life. Life expectancy in good health has already, and will continue, to allow us to reduce retirement expectancy to more reasonable levels. Last but not least, it has been essential to have a long-term and open debate with all actors on these crucial issues (Fig. 1).

3. Active ageing and end-of-career diversity: With the implementation of pension reforms and rising health expectancies, the fourth pillar has developed and will continue to constitute an increasingly significant part of 'retirement' income. This should be positive for economic growth and social progress and, on the whole, for firms and individuals.

In 2021, flexibility has become the norm, and it is not unusual for people to work, mostly part-time, until 70 or over. We believed from the outset that there should not be a single retirement age for all, but end-of-career diversity. Indeed, the notion of retirement age has been gradually replaced by the number of contribution years to pension systems. But, the need for end-of-career diversity must also be accepted if the unfair situation of workers with shorter life expectancies is to be avoided.

Today, such diversity reflects the characteristics of the sectors, professional branches, categories of worker and individual and cultural preferences involved. Financial incentives must be used to encourage flexibility towards the end of occupational life while not ruling out the possibility of a downward trend in retirement age for some.

4. Insurance products needed to play a more important role, since there was still great potential for further adapting savings products to the new and future situations of retirees, and also, of course, to cover the long-term dependency of the very old. For example, 'reverse mortgages' have become much more widespread and better adapted to long retirement and long-term care needs.

Figure 2 provides an estimation of what we believed was to be the future trend for the distribution of retirement income between the 'four pillars' for a representative country in Europe.

\section{Key questions for the insurance sector}

The Four Pillars Research Programme was relevant to the insurance sector in six ways.

\section{Global partnerships between the public and private sectors}

The need to reform social security was felt in all countries. The main objective of this reform was to relatively reduce the substantial share of GDP devoted to social expenditure. The key challenge was to consolidate the partnership between the public and private sectors. Almost all states had to redesign or readjust their welfare policies on health and pensions so as to limit increasing public deficits, which would otherwise place too great a burden upon future generations. 


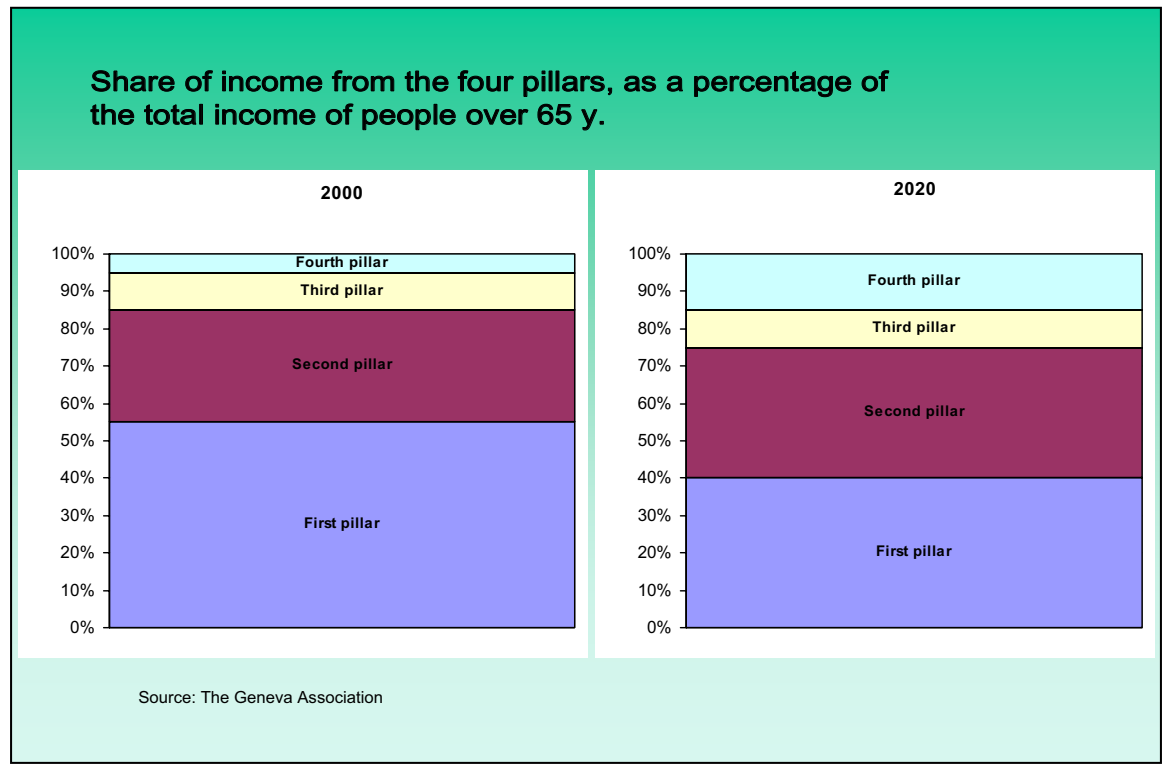

Source Reday-Mulvey, The Geneva Association 2000

Fig. 2 Evolution of the share of income from the four pillars of retirement income (2000-2020)

\section{Development of second- and third-pillar pensions}

With reforms of public pensions aimed at future sustainability-inevitably involving a fall in the relative level of old-age benefits - the development of second- and thirdpillar pensions has become a priority. In many countries, second-pillar pensions are now compulsory and, where not already compulsory, are encouraged by all kinds of financial and fiscal incentives. Private pensions have indeed played an increased role in securing future retirement income.

\section{Research into the extension of working life, i.e. of a fourth pillar and gradual retirement}

Substantial development of second- and third-pillar pensions has not been sufficient to compensate for both longer life expectancy and the rising proportion of people aged over 65 years. With good health expectancy, it is essential to plan for a flexible extension of working life. Pension solutions must still encourage and facilitate this extension, which will also benefit the insurance sector workforce. 


\section{Encouragement of savings and life insurance}

More generally, it is essential to encourage long-term savings for retirement and longer life expectancies. Insurance companies have a key role to play in designing adequate and tailored products to cater to a wide range of needs and means. Fully appreciating the wider social and economic backgrounds against which those products are introduced has been a necessary condition for long-term success.

\section{Age management of the insurance workforce}

In insurance, as in other sectors of the economy, workforce ageing will require planning for improved age management as a matter of urgency. Our studies at the European and international levels have shown that, among other things, continuing training, work-time reduction, job redesign and a review of the seniority-pay principle will still, and increasingly, need to be addressed by individual insurance companies. Codes of employment have started to develop new age management strategies.

\section{Debate and communication}

Developing multi-pillar pension systems and promoting an extension of occupational life depended on certain conditions being met, and needed to be accompanied by a coherent, broad-based, informed and ongoing debate on all these issues. With our research programme and its fourth-pillar proposals, we were able to do pioneering work in this field and made, we believe, a significant contribution to this allimportant debate.

\section{Recognition of the Four Pillars programme}

Our work was well recognised by key organisations, such as the European Commission (which financially supported my book on Gradual Retirement and provided research funding), the OECD, the World Bank and the academic world. Several governments (e.g. Germany, France, the U.K., Switzerland) have taken our proposals into account in their new legislation and reforms. In the press, our proposals and research were mentioned in several prestigious journals and newspapers, such as The Economist and The Financial Times.

"For years The Geneva Association and a few others have been attempting to put the concept of gradual retirement on the policy agenda. That has finally proved successful. The work-retirement transition is now at the centre of the policy stage... and your work was an important influence in formulating our policy advice to OECD ministers."

Peter Hicks, OECD, Paris

More widely, our concepts and proposals on the future of work-The Report to the Club of Rome, The Employment Dilemma: The Future of Work, best-seller and 
translated into seven languages is a key example-have influenced the political debate.

In the late 1990s, we developed an important and very productive collaboration with the Center for Strategic International Studies (CSIS) in Washington, DC-for which Patrick M. Liedtke (then Secretary General of The Geneva Association) was a commissioner-which launched the Global Ageing Initiative (GAI), organised a series of conferences and prepared the important report Meeting the Challenge of Global Aging - Report to World Leaders from the CSIS Commission on Global Aging (CSIS 2002). Among other networks, I was an influent member of the Geneva International Network on Ageing (GINA) and wrote several publications in English and French that contributed to the vulgarisation of our concepts and ideas. Our books and monographs obtained excellent critiques and analyses. I quote here only one example:

"If Europe can successfully extend working life in the careful way advocated by G. Reday-Mulvey in the book 'Working beyond 60' (2005) it would bring benefits to everyone: extending quality of life among older people, a reduction in wastage and an increase in production for employers and a route to social protection system sustainability for policy-makers."

Professor A. Walker, University of Sheffield, Director of the New Dynamics of Ageing (NDA) Programme (2008-2012).

Orio Giarini always insisted that when facing demographic, economic and social challenges, we need to rediscover the working in our information society. We often discussed the fact that we are probably more what we produce than what we consume. Progressively, our societies are being marked by an older population whose maturity is gradually replacing the old cult of youth to give the values of solidarity and social utility the place they deserve.

Open Access This article is licensed under a Creative Commons Attribution 4.0 International License, which permits use, sharing, adaptation, distribution and reproduction in any medium or format, as long as you give appropriate credit to the original author(s) and the source, provide a link to the Creative Commons licence, and indicate if changes were made. The images or other third party material in this article are included in the article's Creative Commons licence, unless indicated otherwise in a credit line to the material. If material is not included in the article's Creative Commons licence and your intended use is not permitted by statutory regulation or exceeds the permitted use, you will need to obtain permission directly from the copyright holder. To view a copy of this licence, visit http://creativecommons.org/licenses/by/4.0/.

\section{References}

CSIS. 2002. Meeting the challenge of global aging-Report to world leaders from the CSIS Commission on Global Aging. https://www.csis.org/analysis/meeting-challenge-global-aging

Delson, L., and G. Reday-Mulvey. 1996. Gradual retirement in the OECD countries. Aldershot: Ashgate.

Giarini, O., and W.R. Stahel. 1993. The limits to certainty-Facing risks in the new service economy, 2nd ed. New York: Springer.

Reday-Mulvey, G. 2005. Working beyond 60-Key policies and practices in Europe. Basingstoke: Palgrave. 
Statista 2020. Where do people spend the longest time in retirement? https://www.statista.com/chart/ 18752/retirement-length-oecd-countries/\#: :text=French\%20citizens\%20are\%20currently\%20the ,in\%202018\%20(latest\%20available).

Publisher's Note Springer Nature remains neutral with regard to jurisdictional claims in published maps and institutional affiliations.

\section{About the author}

Geneviève Reday-Mulvey Social economist and former head of The Four Pillars Programme, 1987-2010. 